\title{
SELECTION OF LANDRACES OF LIMA BEAN FOR FAMILY AGRICULTURE ${ }^{1}$
}

\author{
WILSON VITORINO DE ASSUNÇÃO NETO ${ }^{2 *}$, ARTUR MENDES MEDEIROS ${ }^{3}$, \\ LEONARDO CASTELO BRANCO CARVALHO ${ }^{4}$, CLEMILTON DA SILVA FERREIRA ${ }^{5}$, \\ ANGELA CELIS DE ALMEIDA LOPES ${ }^{4}$, REGINA LUCIA FERREIRA GOMES ${ }^{4}$
}

\begin{abstract}
Lima bean (Phaseolus lunatus L.) is the second most important socioeconomic species of the genus, consisting of a food alternative as green or mature beans. It is an income option for family farmers and the lack of superior varieties makes its recommendation difficult, considering the peculiar lima bean variability. Thus, aimed to select landraces of lima beans based on desirable agronomic traits, enabling their use in breeding programs and later recommendations to family farmers. Evaluation trials were carried out with 14 landraces of lima beans in the municipalities of São Domingos do Maranhão - MA, Teresina - PI, Bom Jesus PI, and Tianguá - CE. The agronomic traits were evaluated: number of days until flowering, number of days until pod maturation, pod length, pod width, pod thickness, number of seeds per pod, 100 -seed weight, and grain yield. The data were initially subjected to univariate analysis of variance to determine the genetic variability in different environments and, subsequently, to multivariate and cluster analyses. The evaluated landraces showed genetic divergence, not being grouped according to geographic origin, demonstrating the existence of similarity between germplasms of rural communities in neighboring states. The varieties Boca de Moça, Raio de Sol, and Fava Branca CE are the earliest; Boca de Moça, Rajada, and Raio de Sol presented the longest pods and largest seeds; and Boca de Moça, Rajada, and Mulatinha are the most productive. Therefore, it qualifies them for recommendation to family farmers and/or incorporation in lima bean breeding programs.
\end{abstract}

Keywords: Phaseolus lunatus L. Agronomic traits. Cluster analysis.

\section{SELEÇÃO DE VARIEDADES CRIOULAS DE FEIJÃO FAVA PARA AGRICULTURA FAMILIAR}

RESUMO - O feijão-fava (Phaseolus lunatus L.) é a segunda espécie de maior importância socioeconômica do gênero, constituindo alternativa alimentar na forma de grãos verdes ou maduros. Sendo uma opção de renda para agricultores familiares, a falta de variedades superiores dificulta a recomendação considerando a peculiar variabilidade do feijão-fava. Objetivou-se selecionar variedades crioulas de feijão-fava com base em caracteres agronômicos, visando a utilização em programas de melhoramento e posterior recomendação para agricultores. Foram conduzidos ensaios de avaliação com 14 variedades crioulas de feijão-fava, nos municípios de São Domingos do Maranhão - MA, Teresina - PI, Bom Jesus - PI e Tianguá - CE. Foram avaliados: número de dias até o início da floração, número de dias até a maturação das vagens, comprimento da vagem, largura da vagem, espessura da vagem, número de sementes por vagem, peso de 100 sementes e produtividade de grãos. Os dados foram submetidos à análise de variância univariada, para determinação da variabilidade genética em diferentes ambientes, e, em seguida, às análises multivariada e de agrupamento. As variedades crioulas apresentam divergência genética, mas não se agrupam segundo origem geográfica, demonstrando a existência de similaridade entre o germoplasma de comunidades rurais estados vizinhos. As variedades Boca de Moça, Raio de Sol e Fava Branca CE são as mais precoces; Boca de Moça, Rajada e Raio de Sol as de vagens mais longas e sementes maiores; e Boca de Moça, Rajada e Mulatinha são as mais produtivas, o que as credencia para recomendação para agricultores familiares e/ou incorporação em programas de melhoramento do feijãofava.

Palavras-chave: Phaseolus lunatus L. Caracteres agronômicos. Análise de agrupamento.

\footnotetext{
${ }^{*}$ Corresponding author

${ }^{1}$ Received for publication in 09/22/2020; accepted in 09/01/2021.

Paper extracted from the masters dissertation of the first author.

${ }^{2}$ Universidade Federal do Piaú, Teresina, PI, Brazil; wilsonassuncao90@gmail.com - ORCID: 0000-0002-0499-6058.

${ }^{3}$ Universidade Federal do Piauí, Bom Jesus, PI, Brazil; artur.medeiros@ufpi.edu.br - ORCID: 0000-0001-8415-4565.

${ }^{4}$ Department of Plant Science, Universidade Federal do Piauí, Teresina, PI, Brazil; cbcleonardo@gmail.com - ORCID: 0000-0001-5722-

9322; acalopes@ufpi.edu.br - ORCID: 0000-0002-9546-5403,rlfgomes@ufpi.edu.br - ORCID: 0000-0002-7700-6959.

${ }^{5}$ Instituto Federal de Educação, Ciência e Tecnologia, Tianguá, CE, Brazil; clemil@ifce.edu.br - ORCID: 0000-0001-7157-9601.
}

Rev. Caatinga, Mossoró, v. 35, n. 1, p. 137 - 147, jan. - mar., 2022 


\section{INTRODUCTION}

Lima bean (Phaseolus lunatus L.), also known as butter bean and sieva bean, is an important source of protein in human nutrition, being consumed as green or dry beans or green beans. It is a typical crop in the Northeast region of Brazil that has been attracting attention due to its acceptance among the population and the high prices paid to producers, mostly family farmers (VIEIRA, 1992). It has high genetic diversity, with high production potential, adapting to different environmental conditions, but preferring humid and hot tropical environments (MAQUET; VEKEMANS; BAUDOIN, 1999).

This species has been used as an alternative source of protein by the population, being consumed in the form of mature or green beans, reducing dependence almost exclusively on common bean. A total of 11,828 tons of dry beans from lima bean were produced in Brazil in 2018 in an area of 36,061 ha. The Northeast region is the main producing region in Brazil, with 11,113 tons of grains produced in an area of 36,919 ha, with a yield of approximately $300 \mathrm{~kg} \mathrm{ha}^{-1}$. The largest producers in the Northeast region are, in descending order, the states of Ceará, Paraíba, Pernambuco, Rio Grande do Norte, Piauí, Maranhão, Alagoas, and Sergipe (IBGE, 2019).

Despite the high added value in marketing, there are still no lima bean cultivars in the National Cultivar Registry (RNC) of the Ministry of Agriculture, Livestock and Food Supply (MAPA) due to the lack of investment in the crop. This makes it impossible for family farmers who work with landrace seeds to have access to agricultural insurance.

The Ministry of Agrarian Development, through Ordinance No. 58, of July 18, 2006, instituted the registration of landrace seeds, with specificities and standards, which allows for the exploitation of their genetic and economic potential, as long as evaluation trials are carried out in different environments for which the varieties are destined (BRASIL, 2006).

Methodologies based on mixed models, with restricted maximum likelihood/best unbiased linear prediction (REML/BLUP) analysis, are currently widely used in plant breeding programs (TORRES FILHO et al., 2017; TORRES et al., 2018; GOMES et al., 2018). This methodology is an ideal genotypic evaluation procedure, as it uses all the effects of the statistical model, addresses the imbalance, considers the genetic relationship between the evaluated plants and the coincidence between selection and recombination units, leading to more accurate estimates and predictions of genetic parameters and genetic values, respectively. BLUP allows the simultaneous use of multiple sources of information, such as those from several experiments set up in one or several sites and evaluated in one or more growing seasons (RESENDE, 2016).

Problems related to biotic and abiotic factors are frequent in the measurement of agronomic traits in the field, which can affect the stage of recommendation of cultivars in breeding programs. The genotypes can show differences in behavior due to regional disparities related to the genotype $\mathrm{x}$ environment interaction, making it difficult the recommendation of varieties to farmers. The identification of more productive landraces of lima beans adapted to the cultivation and suitable for the regional market reduces the risk of losses due to extreme weather events and adds value to the crop, thus contributing to its development.

In this sense, this study aimed to select landraces of lima beans based on desirable agronomic traits, enabling future recommendations for producing regions, aiming at their use in breeding programs, and subsequent recommendations for family farmers.

\section{MATERIAL AND METHODS}

The genetic material consisted of 14 landraces of lima bean (Table 1), which were collected from family farmers in the states of Maranhão, Piauí, and Ceará, and introduced in the Active Phaseolus Germplasm Bank of the Federal University of Piauí (BGP-UFPI).

The study was conducted from December 2018 to October 2019 in the following sites: rural property in the municipality of São Domingos do Maranhão - MA; experimental area of the Department of Crop Production at the Center for Agricultural Sciences of the Federal University of Piauí (UFPI), in the municipality of Teresina - PI; rural property in the municipality of Bom Jesus - PI; and experimental area belonging to the Federal Institute of Ceará (IFCE) in the municipality of Tianguá - CE (Table 2).

The areas used for planting were prepared with the usual plowing and harrowing operations. Base fertilizations were performed with chemical fertilizers to meet the nutritional requirements of the crop, according to the results of the physicochemical analyses of each of the sites that the experiments were set up.

The experimental design consisted of randomized blocks, with four replications. The plots consisted of four rows of $3.5 \mathrm{~m}$, with spacings of $0.80 \mathrm{~m}$ between rows and $0.7 \mathrm{~m}$ between plants. 
Table 1. List of the evaluated landraces of lima beans, showing the entry code in the Active Phaseolus Germplasm Bank of UFPI, common name, and municipality of origin.

\begin{tabular}{|c|c|c|}
\hline BGP-UFPI code & Common name & Origin \\
\hline UFPI 1111 & Fava Branca I MA & São Domingos - MA \\
\hline UFPI 1112 & Branca MA & São Domingos - MA \\
\hline UFPI 1235 & Fava Branca II MA & Buriti Bravo - MA \\
\hline UFPI 1237 & Fava Mulatinha & Farias Brito $-\mathrm{CE}$ \\
\hline UFPI 1245 & Branquinha & Balsas - MA \\
\hline UFPI 1246 & Rajada & Balsas - MA \\
\hline UFPI 1247 & Chumbinho & Miguel Alves - MA \\
\hline UFPI 1248 & Branca CE & Tianguá - CE \\
\hline UFPI 1249 & Fava Branquinha & Tianguá - CE \\
\hline UFPI 1250 & Fava Branca III CE & São Benedito - CE \\
\hline UFPI 1266 & Fava Branca IV CE & Araripi - CE \\
\hline UFPI 1294 & Fava Raio de Sol & Cariaiaçu-CE \\
\hline UFPI 1297 & Boca de Moça & Varjota Assaré - CE \\
\hline UFPI 1299 & Mulatinha & Bom Jesus - PI \\
\hline
\end{tabular}

Table 2. Geographic coordinates and annual precipitation of the municipalities in the states of Ceará, Maranhão, and Piauí where the experiments to evaluate the landraces of lima beans were carried out in the 2018/2019 growing season.

\begin{tabular}{lccccc}
\hline \multicolumn{1}{c}{ Municipality } & Latitude & Longitude & $\begin{array}{c}\text { Altitude } \\
(\mathrm{m})\end{array}$ & $\begin{array}{c}\text { Annual } \\
\text { precipitation }\end{array}$ & $\begin{array}{c}\text { Mean } \\
\text { temperature }\end{array}$ \\
\hline São Domingos - MA & $05^{\circ} 34^{\prime} 33^{\prime \prime} \mathrm{S}$ & $44^{\circ} 23^{\prime} 07^{\prime \prime} \mathrm{W}$ & 191 & 1174 & $26.7^{\circ} \mathrm{C}$ \\
Bom Jesus - PI & $09^{\circ} 04^{\prime} 28^{\prime \prime} \mathrm{S}$ & $44^{\circ} 21^{\prime} 31^{\prime \prime} \mathrm{W}$ & 277 & 1002 & $26.7^{\circ} \mathrm{C}$ \\
Teresina - PI & $05^{\circ} 05^{\prime} 21^{\prime \prime} \mathrm{S}$ & $42^{\circ} 48^{\prime} 07^{\prime \prime} \mathrm{W}$ & 72 & 1349 & $27.6^{\circ} \mathrm{C}$ \\
& & & & & \\
Tianguá - CE & $03^{\circ} 43^{\prime} 56^{\prime \prime} \mathrm{S}$ & $40^{\circ} 59^{\prime} 30^{\prime \prime} \mathrm{W}$ & 775 & 1258 & $22.0^{\circ} \mathrm{C}$ \\
\hline
\end{tabular}

The following traits were evaluated according to the descriptors for Phaseolus lunatus L. (IPGRI, 2001): number of days until flowering (NDF) and number of days until pod maturation (NDM), in days; pod length (PL), pod width (PW), and pod thickness (PT), in mm; number of seeds per pod (NSP); 100-seed weight $(100 \mathrm{SW})$, in $\mathrm{g}$; and grain yield (GY), in $\mathrm{kg} \mathrm{ha}^{-1}$.

The data were subjected to individual analysis of variance, adopting the following statistical model $Y_{i j}=\mu+G_{i}+B_{j}+E_{i j}$, where $Y_{i j}$ is the observation obtained in the plot with the $\mathrm{i}$-th genotype in the $\mathrm{j}$-th block, $\mu$ is the overall mean, $\mathrm{G}_{\mathrm{i}}$ is the effect of the $i$-th genotype $(i=1,2, \ldots, g), B_{j}$ is the effect of the $j$-th block $(j=1,2, \ldots, r)$, and $E_{i j}$ is the mean experimental error. The homogeneity of variances was verified by the maximum Hartley Ftest, calculated by the ratio between the highest and lowest mean squared residual (MSR). The joint analysis of variance was carried out when the value found was lower than seven.

Subsequently, a joint analysis of variance was performed for the traits pod length, pod width, pod thickness, number of grains per pod, 100-seed weight, and grain yield, measured in São Domingos do Maranhão - MA, Teresina - PI, Bom Jesus - PI, and Tianguá - $\mathrm{CE}$, based on the statistical model $Y_{i j k}=\mu+G_{i}+B_{j}+A_{k}+G_{i k}+E_{i j k}$, where $Y_{i j k}$ is the expected performance of the $i$ genotype in the $\mathrm{j}$ block and $\mathrm{k}$ environment, $\mu$ is the overall mean of observations, $G_{i}$ is the main effect of the $i$ genotype, $B_{j}$ is the main effect of the $j$ block, $A_{k}$ is the main 
effect of the $\mathrm{k}$ environment, $\mathrm{GA}_{\mathrm{ik}}$ is the interaction between the $\mathrm{i}$ genotype and $\mathrm{k}$ environment, and $\mathrm{E}_{\mathrm{ijk}}$ is the mean experimental error.

The grouping of genotypes evaluated in more than one environment was obtained from the interaction-free genotypic values $(\mu+$ BLUPs $)$ by applying the mixed model (REZENDE; CARVALHO, 2007) $\mathrm{Y}=\mathrm{Xb}+\mathrm{Zg}+\mathrm{Tgl}+\mathrm{e}$, where $\mathrm{Y}$ is the vector of the observations, $\mathrm{b}$ is the vector of the effects of the block $x$ local combinations added to the overall mean (fixed effects), $g$ is the vector of genotypic effects (assumed to be random), $\mathrm{gl}$ is the vector of the effects of the genotype $x$ location interactions (random), X, Z, and $\mathrm{T}$ are the incidence matrices for the modeled effects, respectively, and e is the vector of errors (random).

The usual hypothesis test of analysis of variance assumes independence from the main effects. The BLUPs are obtained by assuming the effects of genotypes as random. According to Resende (2007), considering the effects of genotypes and $\mathrm{G} \times \mathrm{E}$ interaction as random allows predicting the genetic values via BLUP relative to a given trait. The use of this tool eliminates the effects of the interaction and enables the prediction and ranking of genotypes directly, without the need to obtain adaptability and stability parameters. Therefore, the best genotypes can be identified considering only the genotypic values, eliminating the effect of the environment, which allows for higher accuracy in the prediction.

The genotypic values of each genotype for each trait were subjected to clustering by the Tocher method (sequential)

The individual analysis of variance and the mean comparison test using the Scott-Knott (1974) method were both performed using the Genes program (CRUZ, 2013). The Statistical Environment R (R DEVELOPMENT CORE TEAM, 2018) was used in the analyses of joint variance, genotype clustering, and clustering by the Tocher method (sequential).

\section{RESULTS AND DISCUSSION}

Univariate analyses of variance showed a significant difference between genotypes $(p<0.05$ and $0.01 \%$ ) for most traits (Table 3), except for the number of seeds per pod in São Domingos - MA, Teresina - PI, and Bom Jesus - PI, indicating genetic variability among the studied landraces, with the possibility of selecting those with desirable traits.

Table 3. Mean squares (MS) of individual analyses of variance and coefficients of variation (CV) for the traits number of days until flowering (NDF), number of days until pod maturation (NDM), pod length (PL), pod width (PW), pod thickness (PT), number of seeds per pod (NSP), 100-seed weight (100SW), and grain yield (GY) evaluated in 14 landraces of lima beans in the municipalities of Teresina - PI, São Domingos - MA, Bom Jesus - PI, and Tianguá - CE in the 2018/2019 growing season.

\begin{tabular}{ccccccccc}
\hline & \multicolumn{2}{c}{ Teresina - PI } & \multicolumn{2}{c}{ São Domingos - MA } & \multicolumn{2}{c}{ Bom Jesus - PI } & \multicolumn{2}{c}{ Tianguá - CE } \\
\hline & MS & CV $(\%)$ & MS & CV $(\%)$ & MS & CV (\%) & MS & CV $(\%)$ \\
\hline NDF & $271.6^{* *}$ & 6.3 & $570.9^{* *}$ & 8.0 & - & - & $88.0^{* *}$ & 5.5 \\
NDM & $312.1^{* *}$ & 6.5 & $55.2^{*}$ & 3.9 & - & - & $287.2^{\text {ns }}$ & 8.0 \\
PL & $199.9^{* *}$ & 5.9 & $299.9^{* *}$ & 7.3 & $186.8^{* *}$ & 8.8 & $244.9^{* *}$ & 3.3 \\
PW & $12.0^{* *}$ & 4.8 & $6.3^{* *}$ & 7.1 & $4.2^{* *}$ & 6.1 & $13.9^{* *}$ & 5.8 \\
PT & $1.3^{* *}$ & 7.0 & $3.1^{* *}$ & 9.6 & $1.3^{* *}$ & 7.5 & $2.2^{* *}$ & 5.4 \\
NSP & $0.1^{\text {ns }}$ & 10.2 & $0.1^{\text {ns }}$ & 12.7 & $0.1^{\text {ns }}$ & 11.8 & $0.1^{* *}$ & 6.2 \\
100SW & $332.1^{* *}$ & 15.4 & $301.8^{*}$ & 15.4 & $196.2^{* *}$ & 14.5 & $299.3^{* *}$ & 13.6 \\
GY & $76,863.6^{* *}$ & 25.6 & $10,082.1^{* *}$ & 17.0 & $26,624.1^{* *}$ & 23.2 & $33,497.2^{\text {ns }}$ & 31.9 \\
\hline
\end{tabular}

$\mathrm{ns}, * * * *$ not significant, significant at the $1 \%$ and $5 \%$ probability level, respectively, by the F-test.

Regarding the experimental precision, low to medium coefficients of variation $(\mathrm{CV})$ were obtained for NDF, NDM, PL, PW, and PT, with estimates ranging from 3.9 to $9.6 \%$ in the evaluation environments (Table 3). These CV values are similar to those obtained by Souza et al. (2019) with the lima bean crop and are within the range estimated by Oliveira et al. (2009). These authors evaluated the experimental precision in common bean trials and suggested the use of specific CV ranges for each trait. The low-magnitude $\mathrm{CV}$ values observed in this experiment reflect the good experimental performance, favored by the design with four replications, as an adequate number of replications allows for a decrease in error and an increase in experimental precision. Estimates of coefficients of variation were considered higher for NSP (6.2 to $12.7 \%), 100 \mathrm{SW}$ (13.6 to $15.4 \%$ ), and GY (17.0 to $31.9 \%$ ).

Regarding NDF, the earliest landrace in São Domingos do Maranhão - MA (Table 4) was Fava Branca IV CE, flowering, on average, 70 days after 
germination. The varieties Fava Mulatinha, Chumbinho, Branca CE, Fava Branquinha, and Fava Branca III CE were the latest, flowering at 95, 97, 102, 102, and 104 days, respectively. The earliest landrace in the municipality of Teresina - PI (Table 5) was Boca de Moça, flowering, on average, 73 days after germination. Branca $\mathrm{CE}$, Fava Branquinha, Branquinha, and Fava Branca III CE were the latest varieties, flowering at 94, 100, 100, and 101 days, respectively. The number of days until flowering and the number of days until pod maturation could not be determined in the municipality of Bom Jesus (Table 6). The earliest landraces in Tianguá - CE (Table 7) were Boca de Moça and Raio de Sol, flowering, on average, 42 and 43 days after germination, respectively. The varieties Fava Branca III CE and Fava Branquinha were the latest, flowering at 57 and 59 days, respectively.

Sousa et al. (2015) observed that the period for the beginning of flowering ranged from 31 to 97 days in the evaluation of the ideal edaphoclimatic conditions for performing artificial crosses in lima beans in Teresina - PI, corroborating the data obtained in this study. This trait is extremely important, especially for the drier regions of the semi -arid region, which present scarcity and irregularity of rainfall. Therefore, small farmers will be able to plan to use the best planting time.

Significant differences were observed between varieties regarding the number of days until pod maturation (NDM), with a mean variation of 126 to 138 days in São Domingos do Maranhão - MA (Table 4), 122 to 155 days in Teresina - PI (Table 5), and 139 to 168 days in Tianguá - CE (Table 7). This variation in NDM is similar to that observed in previous studies, such as those carried out by Soares (2018), Gonçalves et al. (2019), and Sousa (2015), due to similar edaphoclimatic conditions. Rezende and Carvalho (2007) also pointed out that the harvest period can be extended when sowing genotypes with different maturation cycles and better quality seeds can be obtained.

Table 4. Means of the traits number of days until flowering (NDF), number of days until pod maturation (NDM), pod length (PL), pod width (PW), pod thickness (PT), number of seeds per pod (NSP), 100 -seed weight (100SW), and grain yield (GY) evaluated in 14 landraces of lima beans in São Domingos - MA in the 2018/2019 growing season.

\begin{tabular}{|c|c|c|c|c|c|c|c|c|}
\hline Variety & NDF (days) & NDM (days) & PL (mm) & $\mathrm{PW}(\mathrm{mm})$ & PT (mm) & NSP & $100 \mathrm{SW}(\mathrm{g})$ & GY $\left(\mathrm{kg} \mathrm{ha}^{-1}\right)$ \\
\hline Fava Branca I MA & $86.7 \mathrm{~b}$ & $134.5 \mathrm{a}$ & $71.7 \mathrm{~b}$ & $15.9 \mathrm{~b}$ & $7.9 \mathrm{c}$ & $2.9 \mathrm{a}$ & $43.4 \mathrm{~b}$ & $312.3 \mathrm{~b}$ \\
\hline Branca MA & $74.0 \mathrm{c}$ & $130.5 \mathrm{~b}$ & $79.6 \mathrm{~b}$ & $16.8 \mathrm{~b}$ & $10.2 \mathrm{a}$ & $2.6 \mathrm{a}$ & $55.6 \mathrm{a}$ & $383.7 \mathrm{a}$ \\
\hline Fava Branca II MA & $73.2 \mathrm{c}$ & $126.5 \mathrm{~b}$ & $72.4 \mathrm{~b}$ & $16.0 \mathrm{~b}$ & $9.5 \mathrm{~b}$ & $2.6 \mathrm{a}$ & $56.0 \mathrm{a}$ & $360.0 \mathrm{~b}$ \\
\hline Fava Mulatinha & $95.7 \mathrm{a}$ & $133.0 \mathrm{a}$ & $70.7 \mathrm{~b}$ & $17.5 \mathrm{a}$ & $7.9 \mathrm{c}$ & $2.7 \mathrm{a}$ & $44.5 \mathrm{~b}$ & $333.2 \mathrm{~b}$ \\
\hline Branquinha & $89.0 \mathrm{~b}$ & $135.5 \mathrm{a}$ & $62.9 \mathrm{~b}$ & $15.1 \mathrm{~b}$ & $8.1 \mathrm{c}$ & $2.8 \mathrm{a}$ & $37.4 \mathrm{~b}$ & $307.5 \mathrm{~b}$ \\
\hline Rajada & $84.7 \mathrm{c}$ & $128.0 \mathrm{~b}$ & $76.8 \mathrm{~b}$ & $19.2 \mathrm{a}$ & $8.1 \mathrm{c}$ & $2.5 \mathrm{a}$ & $52.8 \mathrm{a}$ & $361.0 \mathrm{~b}$ \\
\hline Chumbinho & $97.0 \mathrm{a}$ & $134.0 \mathrm{a}$ & $70.0 \mathrm{~b}$ & $15.6 \mathrm{~b}$ & $9.2 \mathrm{~b}$ & $2.7 \mathrm{a}$ & $51.9 \mathrm{a}$ & $348.2 \mathrm{~b}$ \\
\hline Branca CE & $102.2 \mathrm{a}$ & $133.0 \mathrm{a}$ & $97.1 \mathrm{a}$ & $18.3 \mathrm{a}$ & $7.9 \mathrm{c}$ & $2.6 \mathrm{a}$ & $44.2 \mathrm{~b}$ & $325.9 \mathrm{~b}$ \\
\hline Fava Branquinha & $102.5 \mathrm{a}$ & $138.2 \mathrm{a}$ & $72.5 \mathrm{~b}$ & $18.0 \mathrm{a}$ & $8.5 \mathrm{c}$ & $2.6 \mathrm{a}$ & $35.9 \mathrm{~b}$ & $303.2 \mathrm{~b}$ \\
\hline Fava Branca III CE & $104.0 \mathrm{a}$ & $126.5 \mathrm{~b}$ & $72.5 \mathrm{~b}$ & $17.3 \mathrm{a}$ & $7.8 \mathrm{c}$ & $2.6 \mathrm{a}$ & $41.9 \mathrm{~b}$ & $307.7 \mathrm{~b}$ \\
\hline Fava Branca IV CE & $70.7 \mathrm{c}$ & $126.5 \mathrm{~b}$ & $77.4 \mathrm{~b}$ & $16.0 \mathrm{~b}$ & $10.4 \mathrm{a}$ & $2.5 \mathrm{a}$ & $53.3 \mathrm{a}$ & $453.7 \mathrm{a}$ \\
\hline Fava Raio de Sol & $73.2 \mathrm{c}$ & $134.5 \mathrm{a}$ & $89.8 \mathrm{a}$ & $18.1 \mathrm{a}$ & $9.0 \mathrm{~b}$ & $2.8 \mathrm{a}$ & $58.1 \mathrm{a}$ & $384.4 \mathrm{a}$ \\
\hline Boca de Moça & $77.7 \mathrm{c}$ & $133.0 \mathrm{a}$ & $76.7 \mathrm{~b}$ & $18.2 \mathrm{a}$ & $9.1 \mathrm{~b}$ & $2.5 \mathrm{a}$ & $67.3 \mathrm{a}$ & $437.8 \mathrm{a}$ \\
\hline Mulatinha & $90.5 \mathrm{~b}$ & $132.2 \mathrm{a}$ & $70.1 \mathrm{~b}$ & $16.0 \mathrm{~b}$ & $8.2 \mathrm{c}$ & $2.7 \mathrm{a}$ & $49.5 \mathrm{a}$ & $421.2 \mathrm{a}$ \\
\hline Overall mean & 87.2 & 131.8 & 62.8 & 18.3 & 7.5 & 2.6 & 49.4 & 360.1 \\
\hline
\end{tabular}

Means followed by the same letter in the column do not differ from each other by the Scott-Knot test $(\mathrm{p}<0.05)$.

Regarding the pod length (PL), Raio de Sol had longer pods in Teresina - PI $(84.6 \mathrm{~mm})$ (Table 5), São Domingos - MA (89.8 mm) (Table 4), Bom Jesus - PI (80.2 mm) (Table 6), and Tianguá - CE $(87.9 \mathrm{~mm})$ (Table 7), while Branca CE also stood out in São Domingos - MA (97.1 mm), Bom Jesus - PI (74.6 mm), and Tianguá - CE (90.3 mm). Considering the four environments, the varieties with shorter pods consisted of Branquinha and Chumbinho. Silva and Neves (2011) found that this trait is of paramount importance, as large pods are the most desirable for manual harvesting. Silva et al. (2019) evaluated yield components of lima bean landraces grown in the Agreste region of Paraíba and found variability for pod length, corroborating the results found for the varieties studied in the present research.
The means for pod width (PW) ranged from 14.3 to $19.7 \mathrm{~mm}$, while the mean for pod thickness (PT) ranged from 8.4 to $10.4 \mathrm{~mm}$, both in Teresina PI (Table 5). The varieties in São Domingos do Maranhão - MA (Table 4) presented a variation from 15.6 to $19.2 \mathrm{~mm}$ for PW and 7.8 to $10.4 \mathrm{~mm}$ for PT. The means for PW and PT ranged from 11.7 to $16.8 \mathrm{~mm}$ and 7.7 to $10.6 \mathrm{~mm}$, respectively, in Bom Jesus - PI (Table 6), while the means for PW and PT ranged from 13.6 to $20.7 \mathrm{~mm}$ and 10.4 to $11.8 \mathrm{~mm}$, respectively, in Tianguá - CE (Table 7). According to Dobert and Blevins (1993), the seed size of lima bean plants is an important trait for their physiological development, as larger and more developed seeds occur in wider and thicker pods, and plants developed from larger seeds produced more root nodules and dry matter. 
Table 5. Means of the traits number of days until flowering (NDF), number of days until pod maturation (NDM), pod length (PL), pod width (PW), pod thickness (PT), number of seeds per pod (NSP), 100-seed weight (100SW), and grain yield (GY) evaluated in 14 landraces of lima beans in Teresina - PI in the 2018/2019 growing season.

\begin{tabular}{|c|c|c|c|c|c|c|c|c|}
\hline Variety & NDF (days) & NDM (days) & $\mathrm{PL}(\mathrm{mm})$ & $\mathrm{PW}(\mathrm{mm})$ & PT (mm) & NSP & $100 \mathrm{SW}(\mathrm{g})$ & GY $\left(\mathrm{kg} \mathrm{ha}^{-1}\right)$ \\
\hline Fava Branca I MA & $88.0 \mathrm{~b}$ & $135.0 \mathrm{~b}$ & $65.0 \mathrm{c}$ & $15.1 \mathrm{c}$ & $9.0 \mathrm{~b}$ & $2.5 \mathrm{a}$ & $39.0 \mathrm{c}$ & $269.7 \mathrm{~b}$ \\
\hline Branca MA & $86.5 \mathrm{~b}$ & $125.0 \mathrm{~b}$ & $74.8 \mathrm{~b}$ & $16.3 \mathrm{~b}$ & $10.4 \mathrm{a}$ & $2.5 \mathrm{a}$ & $49.6 \mathrm{c}$ & $350.8 \mathrm{~b}$ \\
\hline Fava Branca II MA & $84.2 \mathrm{~b}$ & $128.2 \mathrm{~b}$ & $76.3 \mathrm{~b}$ & $17.0 \mathrm{~b}$ & $10.0 \mathrm{a}$ & $2.5 \mathrm{a}$ & $50.3 \mathrm{c}$ & $317.0 \mathrm{~b}$ \\
\hline Fava Mulatinha & $90.0 \mathrm{~b}$ & $132.5 \mathrm{~b}$ & $66.4 \mathrm{c}$ & $15.7 \mathrm{c}$ & $9.5 \mathrm{a}$ & $2.7 \mathrm{a}$ & $45.3 \mathrm{c}$ & $311.4 \mathrm{~b}$ \\
\hline Branquinha & $100.2 \mathrm{a}$ & $155.0 \mathrm{a}$ & $59.8 \mathrm{c}$ & $14.3 \mathrm{c}$ & $8.4 \mathrm{~b}$ & $2.9 \mathrm{a}$ & $37.1 \mathrm{c}$ & $280.2 \mathrm{~b}$ \\
\hline Rajada & $89.0 \mathrm{~b}$ & $142.7 \mathrm{a}$ & $75.9 \mathrm{~b}$ & $19.4 \mathrm{a}$ & $9.0 \mathrm{~b}$ & $2.6 \mathrm{a}$ & $56.2 \mathrm{~b}$ & $340.7 \mathrm{~b}$ \\
\hline Chumbinho & $89.0 \mathrm{~b}$ & $133.7 \mathrm{~b}$ & $63.7 \mathrm{c}$ & $15.4 \mathrm{c}$ & $8.9 \mathrm{~b}$ & $2.5 \mathrm{a}$ & $44.4 \mathrm{c}$ & $319.6 \mathrm{~b}$ \\
\hline Branca CE & $94.7 \mathrm{a}$ & $140.2 \mathrm{a}$ & $78.6 \mathrm{~b}$ & $19.7 \mathrm{a}$ & $8.8 \mathrm{~b}$ & $2.5 \mathrm{a}$ & $56.3 \mathrm{~b}$ & $372.4 \mathrm{~b}$ \\
\hline Fava Branquinha & $100.7 \mathrm{a}$ & $142.5 \mathrm{a}$ & $66.8 \mathrm{c}$ & $16.8 \mathrm{~b}$ & $8.9 \mathrm{~b}$ & $2.5 \mathrm{a}$ & $45.9 \mathrm{c}$ & $340.6 \mathrm{~b}$ \\
\hline Fava Branca III CE & $101.7 \mathrm{a}$ & $144.0 \mathrm{a}$ & $62.0 \mathrm{c}$ & $16.8 \mathrm{~b}$ & $8.6 \mathrm{~b}$ & $2.8 \mathrm{a}$ & $42.6 \mathrm{c}$ & $305.2 \mathrm{~b}$ \\
\hline Fava Branca IV CE & $83.5 \mathrm{~b}$ & $128.0 \mathrm{~b}$ & $73.2 \mathrm{~b}$ & $17.6 \mathrm{~b}$ & $9.3 \mathrm{~b}$ & $2.5 \mathrm{a}$ & $38.8 \mathrm{c}$ & $315.7 \mathrm{~b}$ \\
\hline Fava Raio de Sol & $80.7 \mathrm{c}$ & $122.7 \mathrm{~b}$ & $84.6 \mathrm{a}$ & $18.4 \mathrm{a}$ & $9.7 \mathrm{a}$ & $2.7 \mathrm{a}$ & $60.5 \mathrm{~b}$ & $361.7 \mathrm{~b}$ \\
\hline Boca de Moça & $73.2 \mathrm{~d}$ & $130.0 \mathrm{~b}$ & $72.4 \mathrm{~b}$ & $19.7 \mathrm{a}$ & $9.3 \mathrm{~b}$ & $2.5 \mathrm{a}$ & $69.2 \mathrm{a}$ & $489.8 \mathrm{~b}$ \\
\hline Mulatinha & $82.2 \mathrm{c}$ & $131.5 \mathrm{~b}$ & $69.2 \mathrm{c}$ & $16.3 \mathrm{~b}$ & $10.0 \mathrm{a}$ & $2.8 \mathrm{a}$ & $50.4 \mathrm{c}$ & $816.4 \mathrm{a}$ \\
\hline Overall mean & 88.9 & 135.1 & 70.6 & 17.8 & 9.3 & 2.6 & 49.1 & 356.3 \\
\hline
\end{tabular}

Means followed by the same letter in the same column do not differ from each other by the Scott-Knot test $(\mathrm{p}<0.05)$.

Table 6. Means of the traits pod length (PL), pod width (PW), pod thickness (PT), number of seeds per pod (NSP), 100seed weight (100SW), and grain yield (GY) evaluated in 14 landraces of lima beans in Bom Jesus - PI in the 2018/2019 growing season.

\begin{tabular}{|c|c|c|c|c|c|c|}
\hline Variety & PL (mm) & $\mathrm{PW}(\mathrm{mm})$ & PT (mm) & NSP & 100SW (g) & GY $\left(\mathrm{kg} \mathrm{ha}^{-1}\right)$ \\
\hline Fava Branca I MA & $66.1 \mathrm{c}$ & $13.3 \mathrm{c}$ & $9.5 \mathrm{a}$ & $2.8 \mathrm{a}$ & $52.8 \mathrm{c}$ & $269.0 \mathrm{~b}$ \\
\hline Branca MA & $66.8 \mathrm{c}$ & $13.8 \mathrm{c}$ & $9.9 \mathrm{a}$ & $2.6 \mathrm{a}$ & $57.6 \mathrm{c}$ & $466.4 \mathrm{a}$ \\
\hline Fava Branca II MA & $68.5 \mathrm{~b}$ & $13.3 \mathrm{c}$ & $9.6 \mathrm{a}$ & $2.6 \mathrm{a}$ & $58.4 \mathrm{c}$ & $427.8 \mathrm{a}$ \\
\hline Fava Mulatinha & $51.9 \mathrm{c}$ & $13.7 \mathrm{c}$ & $9.2 \mathrm{~b}$ & $2.5 \mathrm{a}$ & $47.8 \mathrm{c}$ & $394.0 \mathrm{a}$ \\
\hline Branquinha & $51.9 \mathrm{~d}$ & $11.7 \mathrm{~d}$ & $8.8 \mathrm{~b}$ & $2.5 \mathrm{a}$ & $33.7 \mathrm{c}$ & $256.0 \mathrm{~b}$ \\
\hline Rajada & $62.1 \mathrm{c}$ & $14.9 \mathrm{~b}$ & $9.6 \mathrm{a}$ & $2.7 \mathrm{a}$ & $59.7 \mathrm{~b}$ & $531.2 \mathrm{a}$ \\
\hline Chumbinho & $58.9 \mathrm{c}$ & $13.1 \mathrm{c}$ & $9.4 \mathrm{a}$ & $2.4 \mathrm{a}$ & $46.6 \mathrm{c}$ & $428.1 \mathrm{a}$ \\
\hline Branca CE & $74.6 \mathrm{a}$ & $16.8 \mathrm{a}$ & $7.7 \mathrm{c}$ & $2.2 \mathrm{a}$ & $46.9 \mathrm{~b}$ & $357.6 \mathrm{~b}$ \\
\hline Fava Branquinha & $60.3 \mathrm{c}$ & $13.8 \mathrm{c}$ & $9.1 \mathrm{~b}$ & $2.4 \mathrm{a}$ & $48.8 \mathrm{c}$ & $434.2 \mathrm{a}$ \\
\hline Fava Branca III CE & $69.0 \mathrm{~b}$ & $15.0 \mathrm{~b}$ & $9.1 \mathrm{~b}$ & $2.5 \mathrm{a}$ & $52.1 \mathrm{c}$ & $491.0 \mathrm{a}$ \\
\hline Fava Branca IV CE & $72.1 \mathrm{~b}$ & $13.5 \mathrm{c}$ & $10.6 \mathrm{a}$ & $2.7 \mathrm{a}$ & $58.9 \mathrm{c}$ & $426.6 \mathrm{a}$ \\
\hline Fava Raio de Sol & $80.2 \mathrm{a}$ & $14.8 \mathrm{~b}$ & $10.0 \mathrm{a}$ & $2.8 \mathrm{a}$ & $59.7 \mathrm{~b}$ & $330.4 \mathrm{~b}$ \\
\hline Boca de Moça & $65.0 \mathrm{c}$ & $13.3 \mathrm{c}$ & $9.6 \mathrm{a}$ & $2.7 \mathrm{a}$ & $57.9 \mathrm{a}$ & $446.4 \mathrm{a}$ \\
\hline Mulatinha & $63.0 \mathrm{c}$ & $14.4 \mathrm{~b}$ & $8.9 \mathrm{~b}$ & $2.4 \mathrm{a}$ & $43.1 \mathrm{c}$ & $318.4 \mathrm{~b}$ \\
\hline Overall mean & 65.7 & 14.0 & 9.3 & 2.5 & 51.7 & 398.4 \\
\hline
\end{tabular}

Means followed by the same letter in the column do not differ from each other by the Scott-Knott test $(\mathrm{p}<0.05)$. 
The number of seeds per pod (NSP) showed no significant difference in the four environments, differing from the results found by Soares (2019), who evaluated 27 ethnovarieties of lima beans in the municipality of Rio Largo - AL and found variability for this trait, which is of paramount importance in the identification of potentially productive genotypes.

Table 7. Means of the traits number of days until flowering (NDF), number of days until pod maturation (NDM), pod length (PL), pod width (PW), pod thickness (PT), number of seeds per pod (NSP), 100-seed weight (100SW), and grain yield (GY) evaluated in 14 landraces of lima beans in Tianguá - CE in the 2018/2019 growing season.

\begin{tabular}{|c|c|c|c|c|c|c|c|c|}
\hline Variety & NDF (days) & NDM (days) & PL (mm) & PW (mm) & PT (mm) & NSP & $100 \mathrm{SW}(\mathrm{g})$ & GY $\left(\mathrm{kg} \mathrm{ha}^{-1}\right)$ \\
\hline Fava Branca I MA & $48.5 \mathrm{c}$ & $162.5 \mathrm{a}$ & $73.7 \mathrm{~d}$ & $15.2 \mathrm{~b}$ & $11.6 \mathrm{c}$ & $3.2 \mathrm{a}$ & $49.4 \mathrm{c}$ & $393.5 \mathrm{a}$ \\
\hline Branca MA & $49.7 \mathrm{c}$ & $149.2 \mathrm{~b}$ & $77.1 \mathrm{c}$ & $16.9 \mathrm{~b}$ & $11.4 \mathrm{a}$ & $3.0 \mathrm{a}$ & $60.2 \mathrm{~b}$ & $394.5 \mathrm{a}$ \\
\hline Fava Branca II MA & $48.0 \mathrm{c}$ & $164.5 \mathrm{a}$ & $75.4 \mathrm{c}$ & $16.6 \mathrm{~b}$ & $11.6 \mathrm{~b}$ & $2.7 \mathrm{a}$ & $57.2 \mathrm{~b}$ & $634.7 \mathrm{a}$ \\
\hline Fava Mulatinha & $51.2 \mathrm{~b}$ & $162.0 \mathrm{a}$ & $68.4 \mathrm{e}$ & $16.8 \mathrm{a}$ & $10.6 \mathrm{c}$ & $2.6 \mathrm{a}$ & $48.7 \mathrm{c}$ & $349.2 \mathrm{a}$ \\
\hline Branquinha & $52.0 \mathrm{~b}$ & $166.0 \mathrm{a}$ & $63.2 \mathrm{f}$ & $13.6 \mathrm{~b}$ & $10.4 \mathrm{c}$ & $3.2 \mathrm{a}$ & $41.5 \mathrm{c}$ & $352.1 \mathrm{a}$ \\
\hline Rajada & $51.5 \mathrm{~b}$ & $139.0 \mathrm{~b}$ & $82.5 \mathrm{~b}$ & $20.7 \mathrm{a}$ & $10.6 \mathrm{c}$ & $2.9 \mathrm{a}$ & $68.1 \mathrm{a}$ & $510.9 \mathrm{a}$ \\
\hline Chumbinho & $49.2 \mathrm{c}$ & $163.5 \mathrm{a}$ & $66.0 \mathrm{f}$ & $14.8 \mathrm{~b}$ & $10.1 \mathrm{~b}$ & $2.7 \mathrm{a}$ & $43.9 \mathrm{c}$ & $340.7 \mathrm{a}$ \\
\hline Branca CE & $53.5 \mathrm{~b}$ & $168.5 \mathrm{a}$ & $90.3 \mathrm{a}$ & $19.7 \mathrm{a}$ & $11.4 \mathrm{c}$ & $2.9 \mathrm{a}$ & $59.9 \mathrm{~b}$ & $593.4 \mathrm{a}$ \\
\hline Fava Branquinha & $59.0 \mathrm{a}$ & $167.0 \mathrm{a}$ & $68.0 \mathrm{e}$ & $17.0 \mathrm{a}$ & $10.5 \mathrm{c}$ & $2.8 \mathrm{a}$ & $47.6 \mathrm{c}$ & $405.9 \mathrm{a}$ \\
\hline Fava Branca III CE & $57.5 \mathrm{a}$ & $163.5 \mathrm{a}$ & $70.2 \mathrm{e}$ & $17.4 \mathrm{a}$ & $11.8 \mathrm{c}$ & $2.8 \mathrm{a}$ & $48.8 \mathrm{c}$ & $376.2 \mathrm{a}$ \\
\hline Fava Branca IV CE & $47.5 \mathrm{c}$ & $162.5 \mathrm{a}$ & $77.1 \mathrm{c}$ & $16.1 \mathrm{~b}$ & $11.4 \mathrm{a}$ & $2.9 \mathrm{a}$ & $55.8 \mathrm{~b}$ & $443.5 \mathrm{a}$ \\
\hline Fava Raio de Sol & $43.0 \mathrm{~d}$ & $149.2 \mathrm{~b}$ & $87.9 \mathrm{a}$ & $18.1 \mathrm{a}$ & $11.8 \mathrm{~b}$ & $2.9 \mathrm{a}$ & $60.0 \mathrm{~b}$ & $455.0 \mathrm{a}$ \\
\hline Boca de Moça & $42.5 \mathrm{~d}$ & $165.5 \mathrm{a}$ & $78.6 \mathrm{c}$ & $19.1 \mathrm{a}$ & $10.4 \mathrm{~b}$ & $2.8 \mathrm{a}$ & $70.4 \mathrm{a}$ & $595.1 \mathrm{a}$ \\
\hline Mulatinha & $46.7 \mathrm{c}$ & $164.0 \mathrm{a}$ & $69.5 \mathrm{e}$ & $16.0 \mathrm{~b}$ & $11.5 \mathrm{c}$ & $2.9 \mathrm{a}$ & $49.8 \mathrm{c}$ & $503.7 \mathrm{a}$ \\
\hline Overall mean & 50.5 & 160.5 & 74.9 & 17.0 & 11.2 & 3.0 & 54.4 & 446.3 \\
\hline
\end{tabular}

Means followed by the same letter in the column do not differ from each other by the Scott-Knott test $(\mathrm{p}<0.05)$.

The variety Boca de Moça stood out with the highest 100-seed weight means in the four environments (69.2 $\mathrm{g}$ in Teresina - PI, $67.3 \mathrm{~g}$ in São Domingos - MA, $58.4 \mathrm{~g}$ in Bom Jesus - PI, and 70.4 $\mathrm{g}$ in Tianguá - CE). The variety Rajada also stood out with means of $59.7 \mathrm{~g}$ in Bom Jesus - PI and 68.1 $\mathrm{g}$ in Tianguá - CE (Tables 3, 4, 5, and 6). Both varieties have long, wide pods and large seeds. The variety Branquinha presented the lowest means of 100-seed weight (37.1 g in Teresina - PI, $37.4 \mathrm{~g}$ in São Domingos - MA, $33.7 \mathrm{~g}$ in Bom Jesus - PI, and $41.5 \mathrm{~g}$ in Tianguá - CE). Barreiro Neto et al. (2015) evaluated this trait in lima bean genotypes in the municipality of João Pessoa - PB and found values ranging from 40.07 to $89.63 \mathrm{~g}$.

The joint analysis of variance showed a significant difference between the 14 landraces of lima beans in the four study environments $(p<0.05$ and 0.01 ) for the traits pod thickness, pod length, pod width, number of pods, number of seeds per pod, 100 -grain weight, and grain yield.

The estimates of the BLUP means for each evaluated trait, corresponding to the interaction-free genotypic values obtained by the sum of BLUPs of each genotype with the overall mean and its confidence interval (Table 8), showed variability between genotypes for all traits.

The genotypic values for pod thickness (Table 8) ranged from 4.6107 (Branquinha) to 5.1954 (Branca MA), with the landraces Fava Branca II MA, Fava Branca IV CE, and Fava Branca I MA those that obtained the highest genotypic values. Pod length (Table 8 ) ranged from 4.0891 to 4.4420 , with the varieties Fava Raio de Sol, Branca CE, and Fava Branca IV CE showing the highest genotypic values. Moreover, pod width (Table 8 ) had a variation from 13.8961 (Branquinha) to 18.5157 (Branca CE), with the varieties Boca de Moça, Rajada, and Branca CE presenting the highest genotypic values.

The genotypic values for the number of pods per plant (Table 9) ranged from 7.0984 (Fava Branca III CE) to 7.6417 (Mulatinha), with the varieties Fava Branca II MA, Fava Branca I MA, and Mulatinha showing the highest means. The number of seeds per pod (Table 9) ranged from 3.0319 (Fava Branca III CE) to 3.4864 (Fava Branca I MA), with the varieties Fava Raio de Sol, Branquinha, and Fava Branca I MA presenting the highest genotypic values.

The genotypic values of 100 -seed weight (Table 10) ranged from 36.9234 (Branquinha) to $64.9327 \mathrm{~g}$ (Boca de Moça), with the varieties Rajada, Fava Raio de Sol, and Boca de Moça showing the highest values.

Grain yield (Table 10) ranged from 10.9240 (Branquinha) to $11.8738 \mathrm{~g}$ (Mulatinha), with the varieties Rajada, Boca de Moça, and Mulatinha being the most productive. According to Cruz, Carneiro and Regazzi (2014), genotypes selected only for their predicted genotypic yield values do not guarantee their better performance when grown under other conditions. In the present study, the selection was based on genotypic values observed in four contrasting environments, showing its reliability. 
Table 8. Genotypic values $(\mathrm{GV}=\mathrm{BLUPs}+\mu)$ and confidence intervals $(\mathrm{CI})$ estimated for 14 landraces of lima bean based on the quantitative traits pod thickness, pod length, and pod width.

\begin{tabular}{llccccc}
\hline \multirow{2}{*}{ Variety } & \multicolumn{2}{c}{ Pod thickness $(\mathrm{mm})$} & \multicolumn{2}{c}{ Pod length (mm) } & \multicolumn{2}{c}{ Pod width (mm) } \\
\cline { 2 - 7 } & GV & CI & GV & CI & GV & CI \\
\hline Fava Branca I MA & 4.78 & $4.55-5.01$ & 4.23 & $4.16-4.30$ & 15.05 & $14.14-15.97$ \\
Branca MA & 5.19 & $4.96-5.42$ & 4.30 & $4.23-4.37$ & 16.02 & $15.10-16.94$ \\
Fava Branca II MA & 4.99 & $4.76-5.22$ & 4.29 & $4.22-4.35$ & 15.83 & $14.92-16.75$ \\
Fava Mulatinha & 4.73 & $4.50-4.96$ & 4.20 & $4.13-4.27$ & 16.00 & $15.08-16.91$ \\
Branquinha & 4.61 & $4.38-4.84$ & 4.08 & $4.02-4.15$ & 13.89 & $12.97-14.81$ \\
Rajada & 4.72 & $4.49-4.95$ & 4.30 & $4.23-4.37$ & 18.50 & $17.58-19.42$ \\
Chumbinho & 4.76 & $4.53-4.99$ & 4.17 & $4.10-4.24$ & 14.91 & $13.99-15.82$ \\
Branca CE & 4.63 & $4.40-4.86$ & 4.43 & $4.36-4.50$ & 18.51 & $17.59-19.43$ \\
Fava Branquinha & 4.71 & $4.48-4.94$ & 4.20 & $4.13-4.27$ & 16.48 & $15.56-17.39$ \\
Fava Branca III CE & 4.72 & $4.49-4.95$ & 4.22 & $4.15-4.29$ & 16.66 & $15.74-17.57$ \\
Fava Branca IV CE & 5.08 & $4.84-5.31$ & 4.31 & $4.24-4.38$ & 15.85 & $14.93-16.77$ \\
Fava Raio de Sol & 4.98 & $4.75-5.21$ & 4.44 & $4.37-4.51$ & 17.34 & $16.42-18.26$ \\
Boca de Moça & 4.82 & $4.59-5.05$ & 4.29 & $4.22-4.36$ & 17.60 & $16.69-18.52$ \\
Mulatinha & 4.83 & $4.60-5.06$ & 4.21 & $4.15-4.28$ & 15.77 & $14.85-16.69$ \\
\hline
\end{tabular}

Table 9. Genotypic values $(\mathrm{GV}=$ BLUPs $+\mu)$ and confidence intervals $(\mathrm{CI})$ estimated for 14 landraces of lima bean based on the quantitative traits number of pods and number of seeds per pod.

\begin{tabular}{llclc}
\hline \multirow{2}{*}{ Variety } & \multicolumn{2}{c}{ Number of pods per plant } & \multicolumn{2}{c}{ Number of seeds per pod } \\
\cline { 2 - 5 } & $\mathrm{GV}$ & $\mathrm{CI}$ & 3.48 & $3.14-3.83$ \\
\hline Fava Branca I MA & 7.59 & $7.02-8.15$ & 3.17 & $2.83-3.52$ \\
Branca I MA & 7.36 & $6.79-7.92$ & 3.12 & $2.77-3.46$ \\
Fava Branca II MA & 7.58 & $7.02-8.15$ & 3.11 & $2.77-3.46$ \\
Fava Mulatinha & 7.32 & $6.76-7.88$ & 3.46 & $3.11-3.80$ \\
Branquinha & 7.52 & $6.95-8.08$ & 3.16 & $2.81-3.50$ \\
Rajada & 7.31 & $6.75-7.88$ & 3.05 & $2.71-3.40$ \\
Chumbinho & 7.43 & $6.87-8.00$ & 3.07 & $2.73-3.42$ \\
Branca II CE & 7.17 & $6.60-7.73$ & 3.15 & $2.81-3.50$ \\
Fava Branquinha & 7.41 & $6.85-7.98$ & 3.03 & $2.68-3.37$ \\
Fava Branca III CE & 7.09 & $6.53-7.66$ & 3.20 & $2.85-3.54$ \\
Fava Branca IV CE & 7.38 & $6.81-7.94$ & 3.38 & $3.04-3.73$ \\
Fava Raio de Sol & 7.20 & $6.64-7.76$ & 3.10 & $2.76-3.45$ \\
Boca de Moça & 7.45 & $6.88-8.01$ & 3.23 & $2.89-3.57$ \\
Mulatinha & 7.64 & $7.07-8.20$ & & \\
\hline
\end{tabular}

Table 10. Genotypic values $(\mathrm{GV}=$ BLUPs $+\mu)$ and confidence intervals $(\mathrm{CI})$ estimated for 14 landraces of lima beans based on the quantitative traits 100-seed weight (100SW) and grain yield (GY).

\begin{tabular}{lcccc}
\hline \multirow{2}{*}{ Variety } & \multicolumn{2}{c}{100 -seed weight $(\mathrm{g})$} & \multicolumn{2}{c}{ Grain yield $\left(\mathrm{kg} \mathrm{ha}^{-1}\right)$} \\
\cline { 2 - 5 } & VG & IC & VG & IC \\
\hline Fava Branca I MA & 46.63 & $39.83-53.44$ & 10.96 & $10.72-11.81$ \\
Branca I MA & 55.24 & $48.43-62.05$ & 11.40 & $10.38-11.46$ \\
Fava Branca II MA & 55.00 & $48.19-61.80$ & 11.55 & $11.31-12.40$ \\
Fava Mulatinha & 47.07 & $40.26-53.88$ & 11.16 & $10.69-11.78$ \\
Branquinha & 36.92 & $30.11-43.72$ & 10.92 & $11.04-12.12$ \\
Rajada & 58.13 & $51.32-64.94$ & 11.58 & $11.04-12.12$ \\
Chumbinho & 47.25 & $40.45-54.06$ & 11.26 & $10.95-12.03$ \\
\hline
\end{tabular}


Table 10. Continuation.

\begin{tabular}{lcccc}
\hline \multirow{2}{*}{ Variety } & \multicolumn{2}{c}{ 100-seed weight $(\mathrm{g})$} & \multicolumn{2}{c}{ Grain yield $\left(\mathrm{kg} \mathrm{ha}^{-1}\right)$} \\
\cline { 2 - 5 } & VG & IC & VG & IC \\
\hline Branca II CE & 52.12 & $45.32-58.93$ & 11.40 & $11.33-12.41$ \\
Fava Branquinha & 45.18 & $38.38-51.99$ & 11.32 & $10.86-11.95$ \\
Fava Branca III CE & 46.80 & $39.99-53.60$ & 11.23 & $10.77-11.86$ \\
Fava Branca IV CE & 51.61 & $44.80-58.42$ & 11.49 & $10.85-11.94$ \\
Fava Raio de Sol & 58.67 & $51.86-65.47$ & 11.37 & $10.62-11.71$ \\
Boca de Moça & 64.93 & $58.12-71.73$ & 11.86 & $10.41-11.50$ \\
Mulatinha & 48.45 & $41.65-55.26$ & 11.87 & $11.00-12.09$ \\
\hline
\end{tabular}

The cluster analysis by the Tocher method using interaction-free genotypic values separated the 14 landraces into five groups (Table 11). Genetically similar varieties were found in Group I: Fava Branquinha, Fava Mulatinha, Chumbinho, and Fava Branca III CE. Pod thickness, pod length, and grain yield were the traits that most contributed to this group. Crosses between these varieties decrease the possibility of obtaining superior genotypes. In this sense, genotypes that fall into the same group indicate that they have similar traits, thus decreasing the opportunities for obtaining superior varieties if crosses are needed in future breeding programs. Therefore, these crosses must be avoided.

Table 11. Clustering of 14 landraces of lima bean by the sequential Tocher method using genotypic values for the quantitative traits: pod thickness (PT), pod length (PL), pod width (PW), number of pods (NP), number of seeds per pod (NSP), 100-seed weight (100SW), and grain yield (GY).

\begin{tabular}{ccc}
\hline Group & Variety & Trait \\
\hline I & Fava Branquinha, Fava Mulatinha, Chumbinho, & Pod thickness, pod length, and grain yield \\
II & Branca MA, Fava Branca IV CE, Fava Branca II & Pod thickness and pod length \\
III & MA & Pod width and pod thickness \\
IV & Branquinha, Fava Branca I MA, Mulatinha & Number of pods and number of seeds per pod \\
V & Fava Raio de Sol & Pod length \\
\hline
\end{tabular}

In Group II, pod thickness and pod length were the traits that contributed to the clustering of the varieties Branca I MA, Fava Branca IV CE, and Fava Branca II MA. The varieties Rajada, Boca de Moça, and Branca II CE were grouped in Group III because they had similar genotypic values for pod width and pod thickness. The traits number of pods and number of seeds per pod contributed to Group IV (Branquinha, Fava Branca I MA, and Mulatinha), while Group V contained only the variety Fava Raio de Sol due to the higher pod length.

The Tocher clustering method allocated the genotypes into groups with higher genetic similarity, a fact that has also been observed by other authors (DIAS et al., 2018; SANTANA et al., 2019). Cruz, Carneiro and Regazzi (2014) suggested that individuals who have the same pattern of dissimilarity should not be crossed among themselves so as not to restrict the variability, avoiding negative effects of gains to be obtained in the selection. Cluster analysis is fundamental in the selection of varieties, as the subsequent crosses to be established must be based on the magnitude of their dissimilarities and the variety potential.

\section{CONCLUSIONS}

The evaluated landraces of lima bean have genetic divergence, not being grouped according to geographic origin, demonstrating the existence of similarity between germplasms of rural communities in neighboring states. This result is very useful in crop improvement, as it is possible to provide greater information on genetic variability, providing more knowledge for variety selection programs.

The landraces Boca de Moça, Raio de Sol, and Fava Branca CE are the earliest; Boca de Moça, Rajada, and Raio de Sol present the longest, widest pods and largest seeds; and Boca de Moça, Rajada, and Mulatinha are the most productive. Therefore, these varieties have desirable agronomic traits and can be recommended for family farmers and/or incorporated in lima bean breeding programs. 


\section{REFERENCES}

BARREIRO NETO, M. et al. Características morfológicas e produtivas em acessos de feijão-fava consorciados. Revista Tecnologia e Ciência Agropecuária, 9: 23-27, 2015.

BRASIL. Ministério de Desenvolvimento Agrário. 2006. Portaria $\mathbf{n}^{\circ} \mathbf{5 8}$, de 18 de julho de 2006. Disponível em: https://www.normasbrasil.com.br/ norma/portaria-58-2006_194879.html. Acesso em: 20 set. 2019.

CRUZ, C. D. GENES - a software package for analysis in experimental statistics and quantitative genetics. Acta Scientiarum, 35: 271-276, 2013.

CRUZ, C. D.; CARNEIRO, P. C. S.; REGAZZI, A. J. Modelos biométricos aplicados ao melhoramento genético. 3 ed. Viçosa, MG: UFV, 2014. 667 p.

DIAS, M. A. R. et al. Divergência genética entre progênies de milho na região centro-sul do estado do Tocantins. Revista Engenharia na Agricultura, 26: 483-496, 2018.

DOBERT, R. C.; BLEVINS, D. G. Effect of seed size and plant growth on nodulation and nodule development in lima bean (Phaseolus lunatus L.). Plant and Soil, The Hague, 148: 11-19, 1993.

GOMES, A. B. S. et al. Genetic gain via REML/ BLUP and selection indices snap bean. Horticultura Brasileira, 36: 195-198, 2018.

GONÇALVES, G. M. C. et al. Dissimilaridades genética entre acessos de feijão-fava utilizando caracteres morfoagronômicos. Revista Caatinga, 32:1125-1132, 2019.

IBGE - Instituto Brasileiro de Geografia e Estatística. Banco de dados agregados: pesquisa: produção agrícola. 2019. Disponível em: <https:// sidra.ibge.gov.br/pesquisa/pam/tabelas $>$. Acesso em: 26 out. 2019 .

IPGRI - International Plant Genetic Resources Institute. Descritores para Phaseolus lunatus (Feijão espadinho). International Plant Genetic Resources Institute. Rome, 2001. 42 p.

MAQUET, A.; VEKEMANS, X. Z.; BAUDOIN, J. P. Phylogenetic study on wild allies of lima bean, Phaseolus lunatus L. (Fabaceae), and implications on its origin. Plant Systematics and Evolution, 218: 43-54, 1999.

OLIVEIRA, R. L. et al. Precisão experimental em ensaios com a cultura do feijão. Ciência $\mathbf{e}$
Agrotecnologia, 33: 113-119, 2009.

R DEVELOPMENT CORE TEAM. R: a language and environment for statistical computing. Vienna: R Foundation for Statistical Computing, 2018 .

RESENDE, M. D. V. SELEGEN-REML/BLUP: sistema estatístico e seleção genética computadorizada via modelos lineares mistos. 1. ed. Colombo, MG: EMBRAPA FLORESTAS, 2007. $359 \mathrm{p}$.

RESENDE, M. D. V. Software Selegen-REML/ BLUP: a useful tool for plant breeding. Crop Breeding and Applied Biotechnology, 16: 330-339, 2016.

REZENDE, P. M.; CARVALHO, E. A. Avaliação de cultivares de soja [Glycine max (L.) Merrill] para o sul de Minas Gerais. Ciência e Agrotecnologia, 31: 1616-1623, 2007.

SANTANA, S. R. A. et al. Genetic divergence among cowpea genotypes by morphoagronomic traits. Revista Caatinga, 32, 3, 841-850, 2019.

SCOTT, A. J.; KNOTT, A. A cluster analysis method for grouping means in the analysis of variance. Biometrics, 30: 507-512, 1974.

SILVA, J. A. L.; NEVES, J. A. Produção de feijãocaupi semi-prostrado em cultivos de sequeiro e irrigado. Revista Brasileira de Ciências Agrárias, 6: 29-36, 2011.

SILVA, S. I. A. et al. Avaliação dos componentes de produção em variedades crioulas de fava cultivadas no Agreste da Paraíba. Revista de Ciências Agrárias, 42: 731-742, 2019.

SOARES, L. A. C. Conservação on farm e avaliação agronômica de variedades crioulas de feijão-fava. 2018. 94 f. Dissertação (Mestrado em Agronomia: Área de Concentração em Genética e Melhoramento) - Universidade Federal do Piauí, Piauí, 2018.

SOARES, V. F. Avaliação da resistência à antracnose em etnovariedades de Phaseolus lunatus L. 2019. f. Dissertação (Mestrado em Proteção de Plantas: Área de Concentração em Fitopatologia) - Universidade Federal de Alagoas, Rio Largo, 2019

SOUSA, A. M. C. B. et al. Determination of ideal conditions to do artificial crosses in Phaseolus lunatus L. Annual Report of the Bean Improvement Cooperative, 58: 95-96, 2015. 
SOUZA, T. P. et al. Selection of promising accessions of lima-beans in Baixada Fluminense-RJ by means of morphoagronomic descriptors.. Magistra, 30: 211-224, 2019.

TORRES, F. E. et al. Selection of soybean genotypes for to cerrado/pantanal ecotone via REML/BLUP. Bioscience Journal, 34: 333-340, 2018.

TORRES FILHO, J. et al., Genotype by environment interaction in green cowpea analyzed via mixed models. Revista Caatinga, 30: 687-697, 2017.

VIEIRA, R. F. A cultura do feijão-fava. Informe Agropecuário, 174: 30-37, 1992. 